\title{
Application of Moringa Oleifera Seed Extract (Mose) in the Removal of Heavy Metals from Tannery Wastewater
}

\author{
- \\ M. A. Tanko ${ }^{1}$, B. Y. Sanda ${ }^{2}$, M. H. Bichi ${ }^{3}$ \\ ${ }^{1,3}$ Department of Civil Engineering, Bayero University Kano, Kano, Nigeria \\ ${ }^{2}$ Department of Civil Engineering, Kebbi State University of Science and Technology Aliero, Kebbi. Nigeria.
}

\begin{abstract}
The main focus of this research work is to investigate the possibility of applying Moringa oleifera seed extract for the removal of heavy metals from tannery wastewater. Samples were collected from effluent discharge points of the $\mathrm{G}_{\mathrm{B}}$ tannery, Muhaza tannery and Z-tannery which are located in Challawa Industrial Area, Kano, Nigeria. The samples analyzed for physico-chemical parameters are $\mathrm{pH}$, temperature, hardness, conductivity, turbidity, alkalinity, total suspended solid, total dissolved solid, calcium, magnesium, chloride, nitrates, sulphates and sulphide and heavy metals such as cadmium, chromium, copper, cobbalt, iron, lead, manganese and zinc. The results show that the final levels of heavy metals after the application of Moringa Oliefera seed extracts were within NESREA acceptable limits. The heavy metal removal efficiencies were as follows; $99.29 \%$ for cadmium, chromium and iron while $96.03 \%, 95.56 \%, 96.84 \%, 87.41 \%, 91.35 \%$ for copper, cobalt, lead, manganese and zinc, respectively. The cheap, easy and environmentally friendly material called Moringa oleifera could be recommended to tannery companies for effective removal of heavy metals so as to have a safe, non-polluting environment and also prevent endangering the lives of aquatic organisms and humans.
\end{abstract}

KEYWORDS: Moringa Oleifera, tannery, wastewater, heavy metal, wastewater

[Received September 26, 2018, Revised June 26, 2019, Accepted October 29, 2019]

Print ISSN: 0189-9546 | Online ISSN: 2437-2110

\section{INTRODUCTION}

Water is one of the essential materials required to sustain life and unfortunately has long been suspected of being the source of much of human illness. Surface and ground water have been increasingly contaminated due to increased industrial and agricultural activities. The public has been increasingly more demanding and engineers are expected to provide waters that are free of many physico-chemical and biological impurities. Increasing population with resultant increase in industrial operations, power production, vehicular traffic and new technologies have created new problems in water supply.

There is a need to understand contaminant fate and effects, as well as to acquire expertise in population control strategies beyond the conventional handling of effluent waste streams. The wide variety of heavy metals and organic chemicals produced and used by different industries has been shown to contaminate surface waters and ground water. These compounds are of public health concerns, and they also may have an adverse effect on the aquatic life.

The uncontrolled releases of waste effluents to large water bodies have negatively affected both water quality and aquatic life (Udosen 2006; Dan'azumi and Bichi, 2010 a, b). Tannery, is a place where animal skins are processed and transformed into leather.

Tanney wastewater contains heavy metals that do not decay and are toxic even at low concentrations. It is thus necessary to

*Corresponding author: sandabashir@gmail.com remove them from the wastewater before disposal. Of the conventional treatments used for the removal of metals from liquid waste, chemical precipitation and ion exchange are the predominant methods. However, they have some limitations as they are uneconomical and do not completely remove metal ions, which make new removal processes necessary (Petroni 2000; Bai et al., 2003, 2004).

As a result of this, local materials such as "Moringa oleifera" are being considered as a substitute. Moringa oleifera seeds extract has been a subject of research by several scholars in this regard (Bichi 2013). Jahn (1986) noted that M. oleifera is a single genus family of shrubs and trees cultivated in the whole of the tropical belt. In Northern Nigeria Sani (1990) reported the use of the leaves as vegetable and for medicinal purposes while the stem is used for demarcating landed properties. Many researchers have reported its use in surface water treatment (Muyibi et al., 1995 a,b; Suarez et al., 2005; Bichi, et al., 2012).

This study therefore seeks to investigate the possibility of applying Moringa oleifera seed extract for the reduction or total removal of heavy metals in tannery wastewaters.

\section{MATERIALS AND METHODS}

This study was conducted in Challawa industrial area located in Kano, Northern Nigeria. It has a number of tanning and textile industries. Samples were collected from the effluent 
of three major tanneries in the study area that discharge their wastewater into the adjourning water courses. The companies are GB-tannery Ltd., Muhaza Company Ltd., and Z-tannery Ltd.

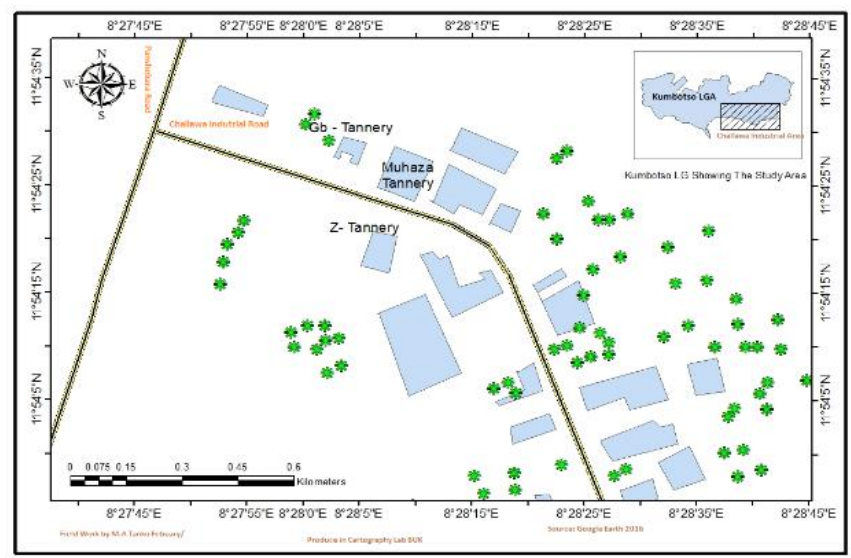

Figure 1: A Map Showing the Research Area.

\section{A. Materials}

Wastewater samples were collected at the main effluent from $\mathrm{G}_{\mathrm{B}}$ Tannery Limited, Muhaza Company Limited and ZTannery Limited. Sample collection was done by employing the standard procedure described by the Department of Waters Affairs and Forestry Pretoria (SA) DWAF (1992) in order to achieve an optimal level of success in sample collection. The following parameters were recorded at the site of collection: name of sample, time and date of collection, place of collection, $\mathrm{pH}$, temperature, conductivity and turbidity. Ten liters (10L) plastic containers after being thoroughly washed with detergent rinsed with clean water and then distilled water then soaked in $5 \% \mathrm{HNO}_{3}$ for 24 hours were used to collect the wastewater samples. The samples were collected three times on weekly bases for each company and transported directly to Civil Engineering Laboratory, Bayero University Kano where it was stored in a refrigerator at a temperature below $4^{0} \mathrm{C}$ for further analysis. A large stock $(5 \mathrm{Kg})$ of good and high quality Moringa oleifera (Zogale seeds) was procured from Bayero University Kano (BUK) Farm.

\section{B. Methods}

\section{1.) Method of Moringa Oleifera Seed Extract Preparation}

Good quality of dry Moringa oleifera was selected and their Pod shells were removed manually and dried in an oven at $60^{\circ} \mathrm{C}$ for $24 \mathrm{hrs}$. Kernels was grounded in a domestic blender and sieved through $600 \mu \mathrm{m}$ stainless steel sieve to obtain its powder.

An Aqueous extract was prepared using $200 \mathrm{ml}$ of distilled water and $25 \mathrm{~g}$ of Moringa oleifera seed powder, mixed by a magnetic stirrer for 60 minutes and allowed to settle for 20 minutes. Moringa oleifera aqueous extract was then finally filtered through $20 \mu \mathrm{m}$ paper filter.

\section{2.) Removal of Turbidity}

This study consists of batch experiments involving rapid mixing, slow mixing and sedimentation. The apparatus consists of six beakers to be agitated simultaneously. $500 \mathrm{ml}$ of the tannery wastewater samples was put in to each 6 oneliter beakers and placed under jar test apparatus.

Various doses of previously prepared Moringa oleifera seed extract; $125 \mathrm{mg} / \mathrm{L}, 250 \mathrm{mg} / \mathrm{L}, 375 \mathrm{mg} / \mathrm{L}, 500 \mathrm{mg} / \mathrm{L}, 625$ $\mathrm{mg} / \mathrm{L}$ and $750 \mathrm{mg} / \mathrm{L}$ ) were added to the beakers containing $500 \mathrm{ml}$ of tannery wastewater. The jar tests were conducted with different rotating speed. This consisted of 100 rotations per minute, rpm for rapid mixing, for 1 minute and $30 \mathrm{rpm}$ for 10 minutes for flocculation. After the agitation, the suspensions were allowed to settle for 20 minutes and about $100 \mathrm{ml}$ of the settled water was carefully decanted from the top of each beaker and its colour, turbidity, $\mathrm{pH}$, alkalinity and heavy metals concentrations determined.

\section{3.) Analyses of Heavy Metals}

For the chemical analysis of the sample, the Open-Beaker Digestion (OBD) method was employed using $\mathrm{HNO}_{3}$ as described in laboratory procedure for fertilizer and water analysis. The heavy metals were chromium, copper, cadmium, zinc, cobalt, iron, lead, and manganese in $(\mathrm{mg} / \mathrm{L})$ were carried out using an Atomic Absorption Spectrophotometer (AAS) and all concentrations were determined using the absorbance made with air-acetylene flame. The wastewaters were treated with different concentrations of the aqueous extract of Moringa oleifera and the results were then measured and analysed accordingly.

The analysis was carried out using an Atomic Absorption Spectrophotometer (Buck Scientific AAS, Model VGP 210) which is a selective and sensitive method used in the determination of metal and metalloids. All concentration was determined using the absorbance made with air-acetylene flame. Eight working solutions were prepared from stock solutions for each of the metals by successive serial dilution and each of the standard solutions was then aspirated into the flame of AAS.

Physico-chemical parameters determination such as $\mathrm{pH}$, temperature, turbidity, settleable solids, suspended solids, dissolved solids, conductivity, hardness, alkalinity, chloride, sulphate, calcium were all carried out.

\section{RESULTS AND DISCUSSION}

The physicochemical and heavy metals parameters of the wastewater from the three (3) tanneries were determined. In comparison with the NESREA regulation for the maximum allowable concentration of heavy metals, it was found out that all the concentration exceeded the NESREA regulation except for temperature and $\mathrm{pH}$. The presented in Table 1. 
Table 1: Physicochemical and Heavy Metals Parameters in Tannery Wastewaters from $G_{B}$, Muhaza $(M)$ and Z-Tanneries Limited $(Z)$.

\begin{tabular}{|c|c|c|c|c|c|}
\hline S/No & Parameters & $\begin{array}{l}\text { NESREA } \\
\text { Regulations } \\
\text { on Tannery } \\
\text { Effluent }\end{array}$ & $\mathrm{G}_{\mathrm{B}}$ & M & $\mathrm{Z}$ \\
\hline 1 & $\mathrm{pH}$ & $6-9$ & 8.80 & 9.10 & 9.05 \\
\hline 2 & $\begin{array}{l}\text { Temperature } \\
\left({ }^{\circ} \mathrm{C}\right)\end{array}$ & 40 & 26.80 & 29.1 & 29.30 \\
\hline 3 & $\begin{array}{l}\text { Hardness } \\
(\mathrm{mg} / \mathrm{l})\end{array}$ & - & 228.2 & 187.6 & 159.8 \\
\hline 4 & $\begin{array}{l}\text { Conductivity } \\
(\mu \mathrm{S} / \mathrm{cm})\end{array}$ & - & 2,650 & 2,780 & 2480 \\
\hline 5 & $\begin{array}{l}\text { Turbidity } \\
\text { (NTU) }\end{array}$ & - & 871 & 928 & 793 \\
\hline 6 & $\begin{array}{l}\text { Alkalinity (mg } \\
\left.\mathrm{CaCO}_{3} / \mathrm{l}\right) \\
\text { Total }\end{array}$ & - & 709 & 1,025 & 845 \\
\hline 7 & $\begin{array}{l}\text { Suspended } \\
\text { Solids (mg/l) } \\
\text { Total }\end{array}$ & 25 & 489 & 567 & 523 \\
\hline 8 & $\begin{array}{l}\text { Dissolved } \\
\text { Solids (mg/l) }\end{array}$ & 2000 & 2,667 & 2,586 & 2,534 \\
\hline 9 & $\begin{array}{l}\text { Calcium } \\
(\mathrm{mg} / \mathrm{l})\end{array}$ & - & 102.8 & 98.42 & 105.1 \\
\hline 10 & $\begin{array}{l}\text { Magnesium } \\
(\mathrm{mg} / \mathrm{l})\end{array}$ & - & 6.80 & 8.40 & 10.90 \\
\hline 11 & Chloride & 0.5 & 206.9 & 109.1 & 147.2 \\
\hline 12 & Nitrates (mg/l) & - & 34 & 29 & 28 \\
\hline 13 & $\begin{array}{l}\text { Sulphates } \\
(\mathrm{mg} / \mathrm{l})\end{array}$ & - & 734 & 876 & 930 \\
\hline 14 & $\begin{array}{l}\text { Sulphide } \\
(\mathrm{mg} / \mathrm{l})\end{array}$ & 1 & 130 & 198 & 150 \\
\hline 15 & $\begin{array}{l}\text { Cadmium } \\
(\mathrm{mg} / \mathrm{l})\end{array}$ & 0.02 & 16.40 & 11.80 & 12.89 \\
\hline 16 & $\begin{array}{l}\text { Chromium } \\
(\mathrm{mg} / \mathrm{l})\end{array}$ & 0.1 & 9.80 & 8.70 & 8.98 \\
\hline 17 & Copper (mg/l) & 0.5 & 5.80 & 4.40 & 3.97 \\
\hline 18 & Cobalt (mg/l) & 0.5 & 1.80 & 1.90 & 2.85 \\
\hline 19 & Iron $(\mathrm{mg} / \mathrm{l})$ & - & 1.40 & 1.10 & 1.49 \\
\hline 20 & Lead (mg/l) & 0.1 & 1.90 & 1.40 & 1.73 \\
\hline 21 & $\begin{array}{l}\text { Manganese } \\
(\mathrm{mg} / \mathrm{l})\end{array}$ & 1.0 & 2.70 & 3.00 & 1.99 \\
\hline 22 & Zinc (mg/l) & 2 & 10.40 & 11.20 & 9.93 \\
\hline
\end{tabular}

$\mathrm{pH}$ value for $\mathrm{G}_{\mathrm{B}}$ tannery was found within the guideline range of 6-9, Muhaza tannery exhibits a $\mathrm{pH}$ of alkaline range while Z-tannery exhibits the same trend. It was observed that Moringa oleifera seed extract had no much effect on this parameter unlike other physicochemical parameters as in Figure 2.

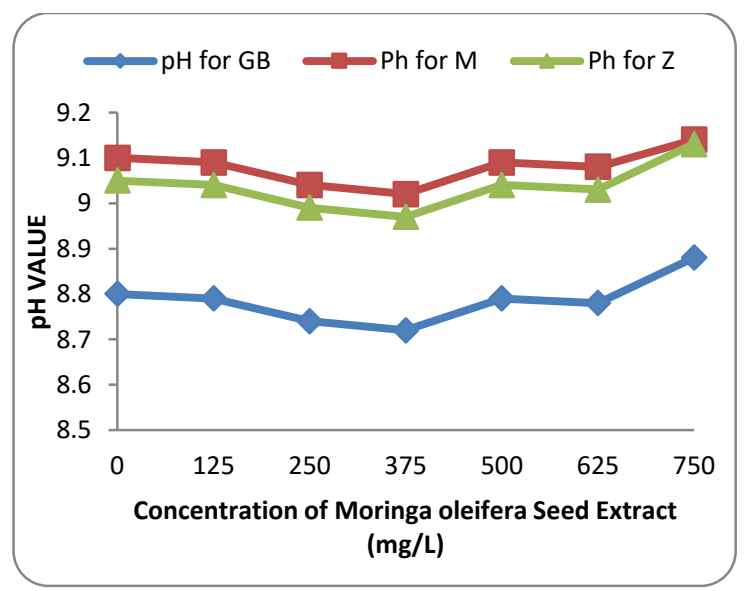

Figure 2: pH Chart for $\mathrm{G}_{\mathrm{B}}$, Muhaza and Z-Tanneries Limited.
The temperature of the $\mathrm{G}_{\mathrm{B}}$ tannery was in the range of 26.10 ${ }^{0} \mathrm{C}-26.77{ }^{\circ} \mathrm{C}$ with the control sample of $26.80{ }^{\circ} \mathrm{C}$, Muhaza tannery's temperature was in the range of $28.34{ }^{\circ} \mathrm{C}-29.07{ }^{\circ} \mathrm{C}$ with the control sample of $29.10^{\circ} \mathrm{C}$ and Z-tannery temperature was in the range of $28.54{ }^{\circ} \mathrm{C}-29.27{ }^{\circ} \mathrm{C}$ with the control sample of $29.30{ }^{\circ} \mathrm{C}$. All temperatures were lower than $40{ }^{\circ} \mathrm{C}$ guideline for wastewaters as clearly shown in Figure 3.

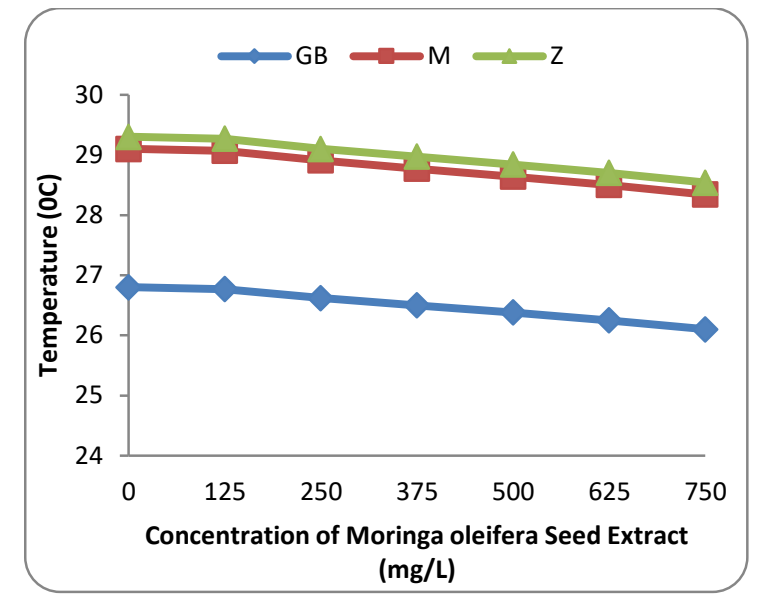

Figure 3: Temperature Chart for $\mathbf{G}_{\mathrm{B}}$, Muhaza and Z-Tanneries Limited.

The hardness of water samples with initial concentrations of $228.20 \mathrm{mg} / \mathrm{L}, 187.60 \mathrm{mg} / \mathrm{L}$ and $159.80 \mathrm{mg} / \mathrm{L}$ from the three tanneries in question were found reduced with the effect of Moringa oleifera seed extract although no guideline value was specified for hardness by the agency and this could be as a result of coagulation mechanism of Moringa oleifera coagulant protein which described it as an adsorption, charge neutralization and inter particle bridging as shown in Figure 4.

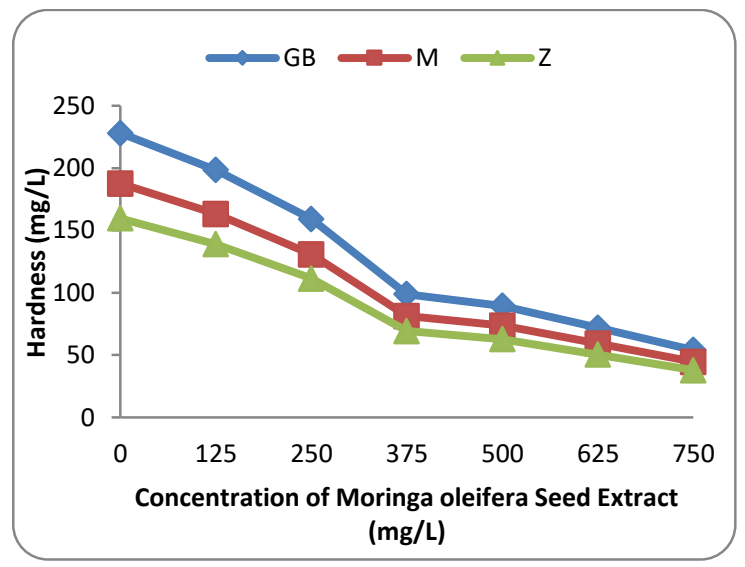

Figure 4: Hardness Chart for $G_{\mathrm{B}}$, Muhaza and Z-Tanneries Limited.

The conductivity exhibited by Muhaza tannery was found to be the highest with a value of $2780 \mu \mathrm{S} / \mathrm{cm}$ followed by $\mathrm{G}_{\mathrm{B}}$ tannery with a value of $2650 \mu \mathrm{S} / \mathrm{cm}$ and Z-tannery with a value of $2480 \mu \mathrm{S} / \mathrm{cm}$ but with the aid of Moringa oleifera seed extract the values were found below $2000 \mu \mathrm{S} / \mathrm{cm}$ even though no guideline figure was specified for the conductivity by the 
agency. These can be related to the high concentration of total dissolved solids in the three tanneries as shown in Figure 5.

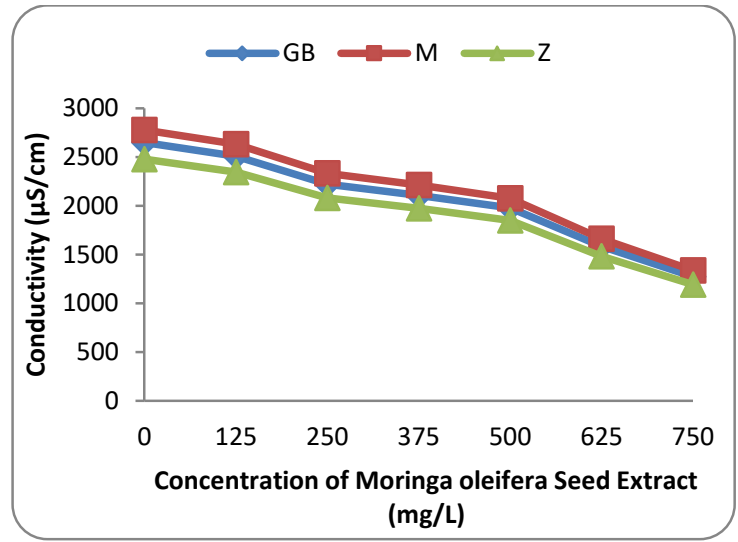

Figure 5: Conductivity Chart for $\mathrm{G}_{\mathrm{B}}$, Muhaza and Z-Tanneries Limited.

The turbidity of Muhaza tannery with the value of 928 NTU was found to be the highest followed by that of $G_{B}$ tannery 871 NTU and Z-tannery 793 NTU and this can be attributed to the high concentration of suspended solids in the samples. No guideline value was given for the turbidity by the agency but at the end of the experimental test, the value of turbidity reduced consistently for the three tanneries at optimum dosage of $500 \mathrm{mg} / \mathrm{L}$ before it later rose when 625 $\mathrm{mg} / \mathrm{L}$ extract was added which shows there is destabilization of the flocks due to excess positive ions in the Moringa oleifera seed extract and its very efficient in turbidity removal, Although, it was observed that a more settling time is required after $500 \mathrm{mg} / \mathrm{L}$ addition of the extract as shown in Figure 6.

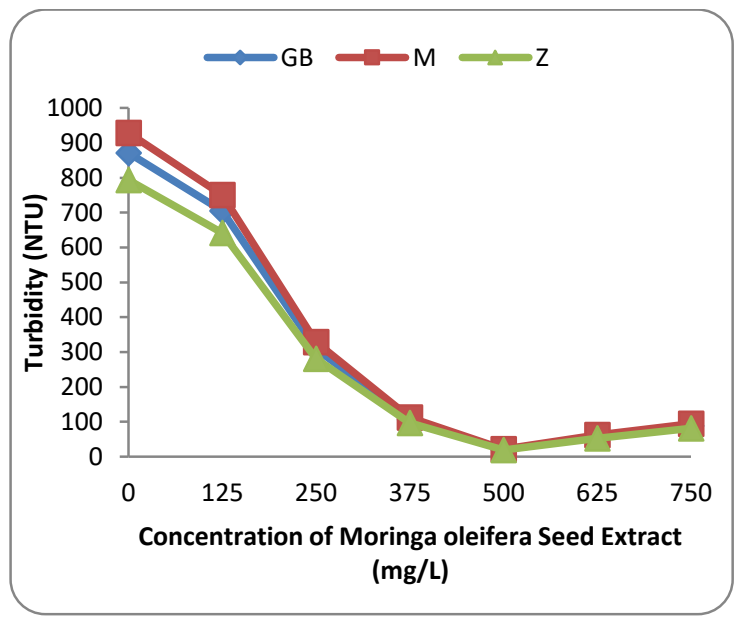

Figure 6: Turbidity Chart for $\mathrm{G}_{\mathrm{B}}$, Muhaza and Z-Tanneries Limited.

The Alkalinity in $\mathrm{mg} / \mathrm{L}$ of $\mathrm{CaCO}_{3}$ in the tannery wastewaters were higher in Muhaza tannery with a control sample of $1025 \mathrm{mg} / \mathrm{L}, 845 \mathrm{mg} / \mathrm{L}$ for Z-tannery and $709 \mathrm{mg} / \mathrm{L}$ for $\mathrm{G}_{\mathrm{B}}$ tannery but at the end of the laboratory test, the values were dropped with the effect of Moringa oleifera seed extract as shown in Figure 7.

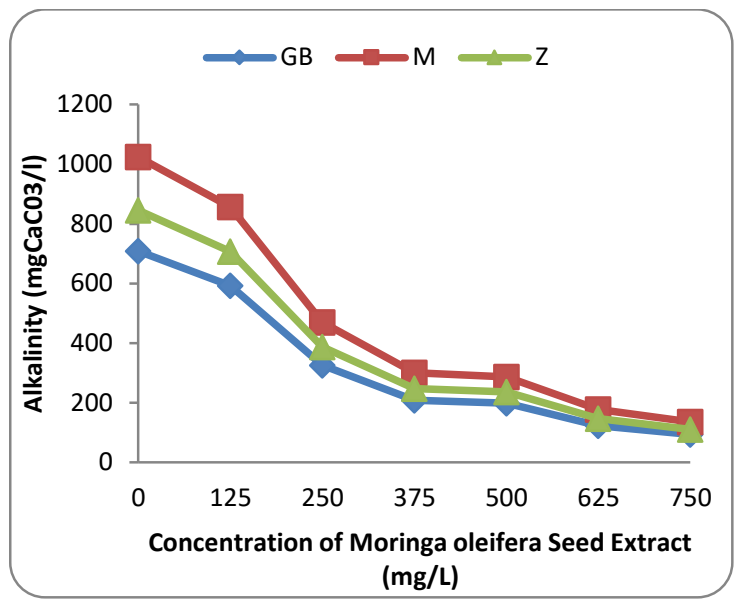

Figure 7: Alkalinity Chart for $\mathrm{G}_{\mathrm{B}}$, Muhaza and Z-Tanneries Limited.

The suspended solids in tanneries in question were significantly higher than the $25 \mathrm{mg} / \mathrm{L}$ National Environmental Standards and Regulations Agency (NESREA) guideline for tannery water, while Muhaza tannery exhibits higher control sample of $567 \mathrm{mg} / \mathrm{L}$ but was reduced at the end of the test to $22.03 \mathrm{mg} / \mathrm{L}$ at $625 \mathrm{mg} / \mathrm{L}$. It was observed that the soluble particles in the water attach to the active agent of Moringa oleifera seed extract that bond them together creating large flocs in the water as shown in Figure 8.

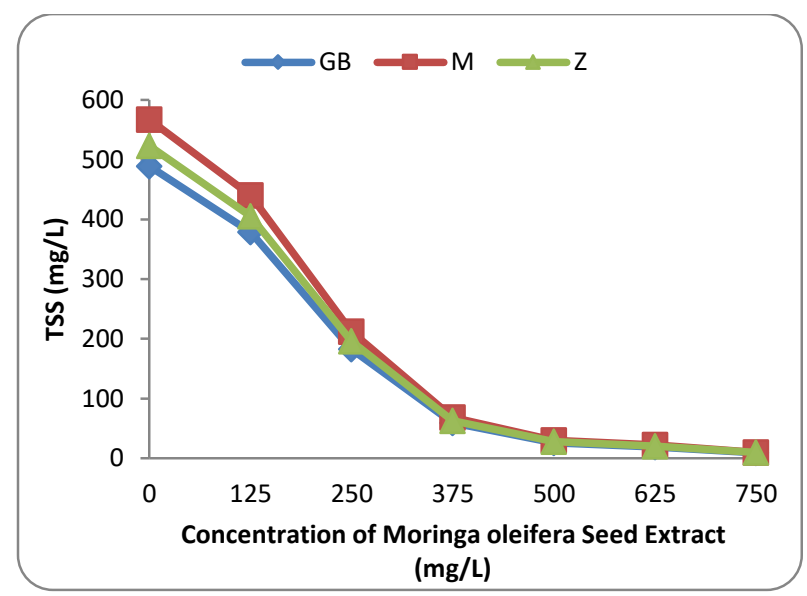

Figure 8: Total Suspended Solid Chart for GB, Muhaza and ZTanneries Limited.

The concentration of total dissolved solids was not in conformity with NESREA guideline as all values were greater than $2000 \mathrm{mg} / \mathrm{L}$. The highest concentration was observed in $\mathrm{G}_{B}$ tannery with a concentration of $2667 \mathrm{mg} / \mathrm{L}$ followed by Muhaza tannery having a TDS concentration of $2586 \mathrm{mg} / \mathrm{L}$, the least TDS concentration was observed in Z-tannery with a value of $2534 \mathrm{mg} / \mathrm{L}$, while their TDS concentrations were found reduced below the stated guideline at the end of the experiment as shown in Figure 9. 


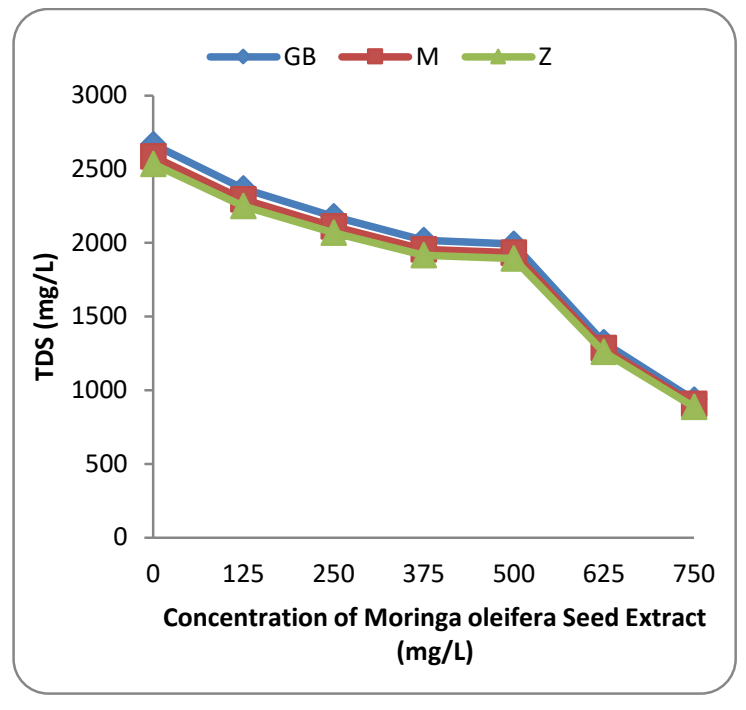

Figure 9: Total Dissolved Solid Chart for $\mathbf{G}_{\mathrm{B}}$, Muhaza and Z-Tanneries Limited.

The concentration of calcium in Z-tannery exhibits highest value of $105.1 \mathrm{mg} / \mathrm{L}, 102.8 \mathrm{mg} / \mathrm{L}$ for $\mathrm{G}_{\mathrm{B}}$ tannery and $98.42 \mathrm{mg} / \mathrm{L}$ for Muhaza tannery wastewaters, while all were reduced far below the values of their control samples at various percentages of Moringa oleifera seed extract as shown in Figure 10.

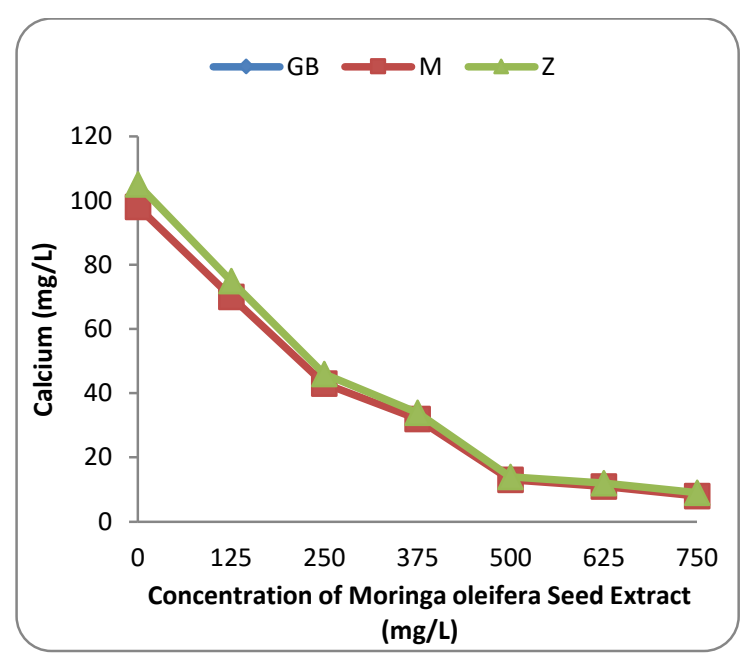

Figure 10: Calcium Chart for $G_{B}$, Muhaza and Z-Tanneries Limited.

The magnesium content of $\mathrm{G}_{\mathrm{B}}$ tannery, Muhaza tannery and Z-tannery were found to be $6.8 \mathrm{mg} / \mathrm{L}, 8.4 \mathrm{mg} / \mathrm{L}$ and 10.9 $\mathrm{mg} / \mathrm{L}$ respectively. The concentrations were reduced at the end of the experiment with the variation in the dosages of Moringa oleifera as shown in Figure 11.

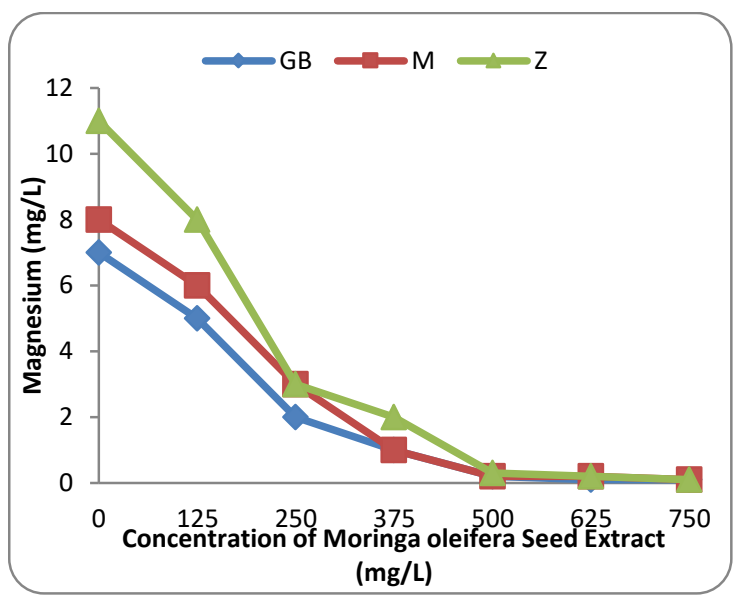

Figure 11: Magnesium Chart for $G_{\mathrm{B}}$, Muhaza and Z-Tanneries Limited.

The chloride concentration obtained in most of the tannery wastewater samples were higher than the NESREA guideline value of $0.5 \mathrm{mg} / \mathrm{L}$, with the $\mathrm{G}_{\mathrm{B}}$ tannery exhibits much higher concentrations of $206.9 \mathrm{mg} / \mathrm{L}$ followed by Z-tannery exhibits $147.2 \mathrm{mg} / \mathrm{L}$ and then Muhaza tannery exhibits $109.10 \mathrm{mg} / \mathrm{L}$. The concentrations were reduced below the guideline value at $750 \mathrm{mg} / \mathrm{L}$ of Moringa oleifera seed extract as shown in Figure 12.

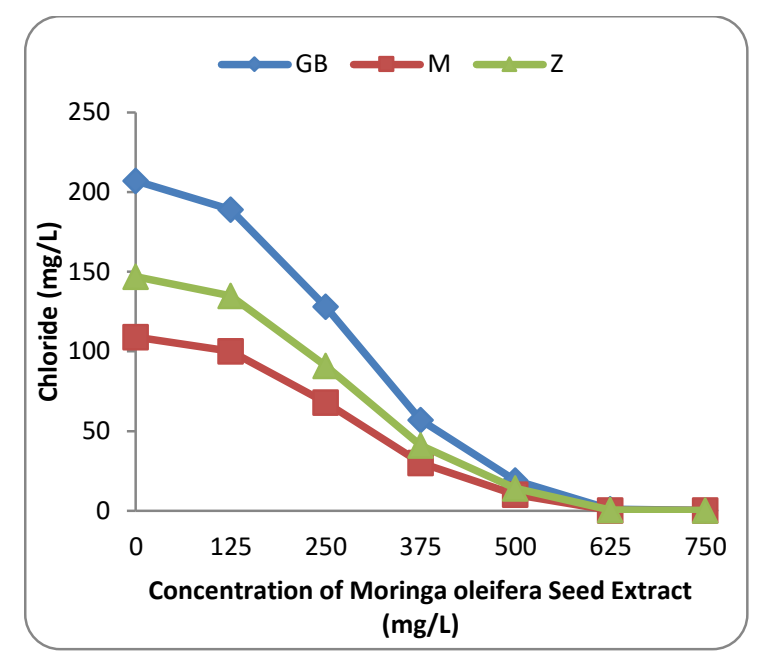

Figure 12: Chloride Chart for $\mathbf{G}_{\mathrm{B}}$, Muhaza and Z-Tanneries Limited.

The nitrates concentrations of $\mathrm{G}_{\mathrm{B}}$ tannery, Muhaza tannery and Z-tannery were found to be $34.00 \mathrm{mg} / \mathrm{L}, 29.00 \mathrm{mg} / \mathrm{L}$ and $28.00 \mathrm{mg} / \mathrm{L}$ respectively. The concentrations were reduced at the end of the experiment with the variation in the dosages of Moringa oleifera seed extract as shown in Figure 13. 


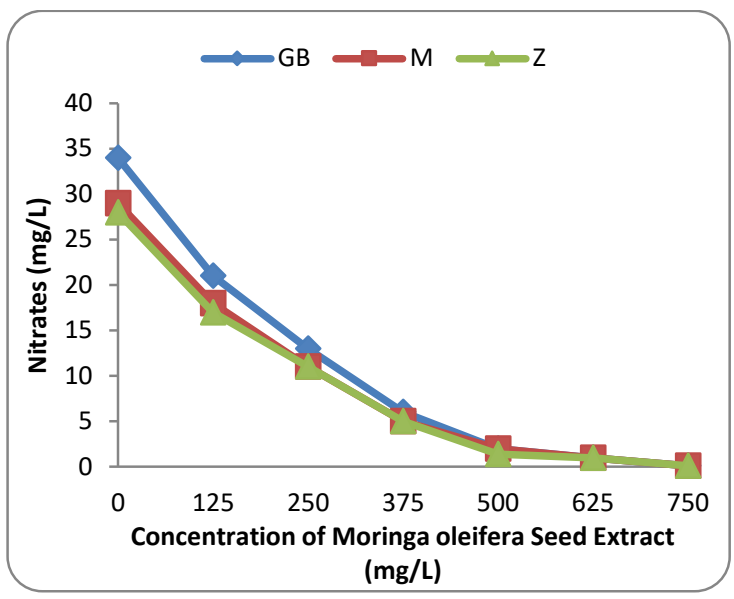

Figure 13: Nitrates Chart for $G_{B}$, Muhaza and Z-Tanneries Limited.

The sulphates concentration seems to be much from Ztannery sample with a control sample of $930 \mathrm{mg} / \mathrm{L}$ followed by Muhaza tannery with a control sample of $876 \mathrm{mg} / \mathrm{L}$ and $\mathrm{G}_{B}$ tannery with a control sample of $734 \mathrm{mg} / \mathrm{L}$. The concentrations reduced to minimal level compare to their initially exhibited values as shown in Figure 14.

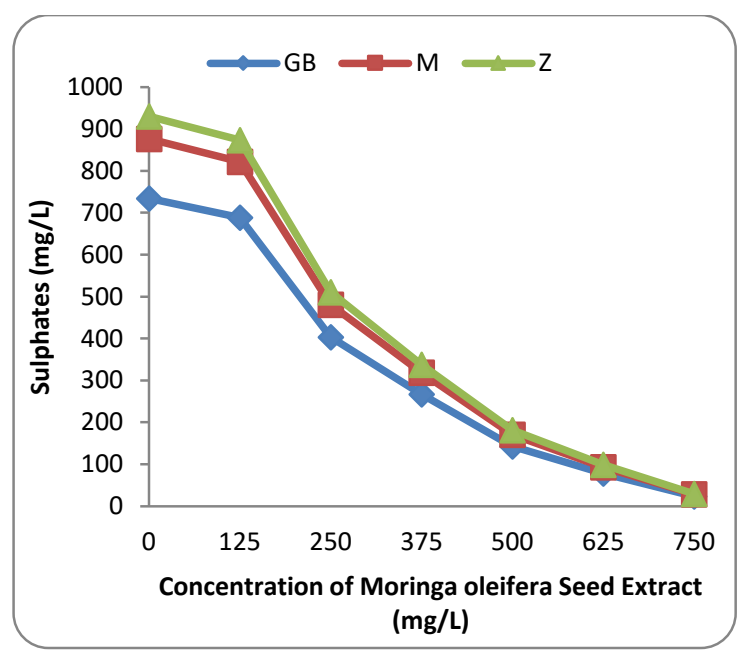

Figure 14: Sulphates Chart for $G_{B}$, Muhaza and Z-Tanneries Limited.

The concentration of sulphides was higher for the three tanneries than $1 \mathrm{mg} / \mathrm{L}$ NESREA value with Muhaza tannery exhibits higher concentration value of $198 \mathrm{mg} / \mathrm{L}$, followed by Z-tannery exhibits $150 \mathrm{mg} / \mathrm{L}$ and $\mathrm{G}_{\mathrm{B}}$ tannery exhibits 130 $\mathrm{mg} / \mathrm{L}$. The concentrations were reduced below the guideline value at $750 \mathrm{mg} / \mathrm{L}$ of the Moringa oleifera seed extract as shown in Figure 15.

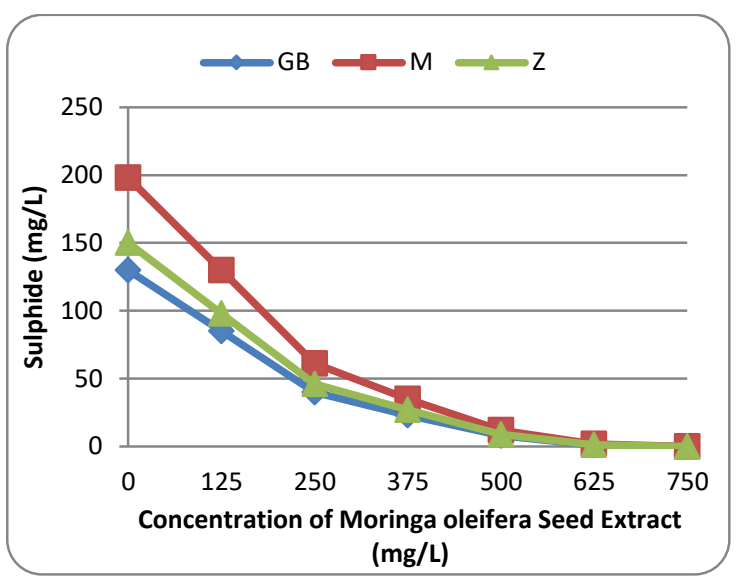

Figure 15: Sulphide Chart for $G_{B}$, Muhaza and Z-Tanneries Limited.

The concentration of cadmium in $\mathrm{G}_{\mathrm{B}}$, Muhaza and Ztanneries were found to be $16.40 \mathrm{mg} / \mathrm{L}, 11.80 \mathrm{mg} / \mathrm{L}$ and 12.8 $\mathrm{mg} / \mathrm{L}$ respectively which was significantly higher than the NESREA guidelines for tannery wastewater of $0.02 \mathrm{mg} / \mathrm{L}$. The concentration of cadmium was reduced from $16.40 \mathrm{mg} / \mathrm{L}-0.01$ $\mathrm{mg} / \mathrm{L}, 11.80 \mathrm{mg} / \mathrm{L}-0.01 \mathrm{mg} / \mathrm{L}$ and $12.89 \mathrm{mg} / \mathrm{L}-0.01 \mathrm{mg} / \mathrm{L}$ for $\mathrm{G}_{\mathrm{B}}$, Muhaza and Z-tanneries respectively at $750 \mathrm{mg} / \mathrm{L}$ of Moringa oleifera seed extract and its obviously shows an efficient removal of cadmium for the three tanneries as follows; $99.94 \%, 99.94 \%$ and $99.92 \%$ respectively. It was observed that Moringa oleifera consists of adsorption and neutralization of the colloidal positive charges that attract the negatively charged impurities and metals in water as shown in Figure 16.

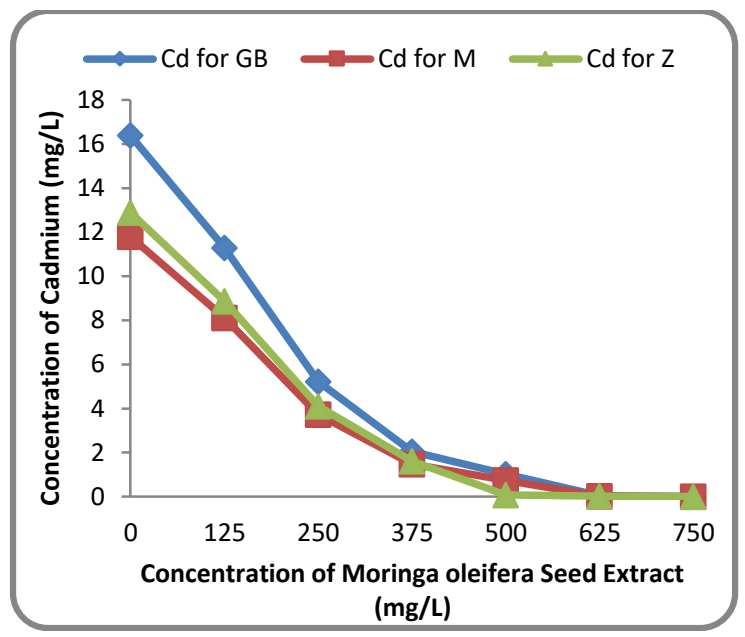

Figure 16: Cadmium (Cd) Chart for $\mathrm{G}_{\mathrm{B}}$, Muhaza and Z-Tanneries Limited.

The concentration of chromium in $\mathrm{G}_{\mathrm{B}}$, Muhaza and Z-tanneries were found to be $9.80 \mathrm{mg} / \mathrm{L}, 8.70 \mathrm{mg} / \mathrm{L}$ and $8.98 \mathrm{mg} / \mathrm{L}$ respectively which was significantly higher than the NESREA guidelines for tannery wastewater of $0.1 \mathrm{mg} / \mathrm{L}$. The concentration of chromium was reduced from $9.80 \mathrm{mg} / \mathrm{L}$ $0.07 \mathrm{mg} / \mathrm{L}, 8.70 \mathrm{mg} / \mathrm{L}-0.06 \mathrm{mg} / \mathrm{L}$ and $8.98 \mathrm{mg} / \mathrm{L}-0.06 \mathrm{mg} / \mathrm{L}$ for the three tanneries at $625 \mathrm{mg} / \mathrm{L}$ of Moringa oleifera seed 
extract and therefore shows an efficient removal of chromium at $99.29 \%, 99.31 \%$ and $99.93 \%$ respectively. It was observed that Moringa oleifera consists of adsorption and neutralization of the colloidal positive charges that attract the negatively charged impurities and metals in water as shown in Figure 17.

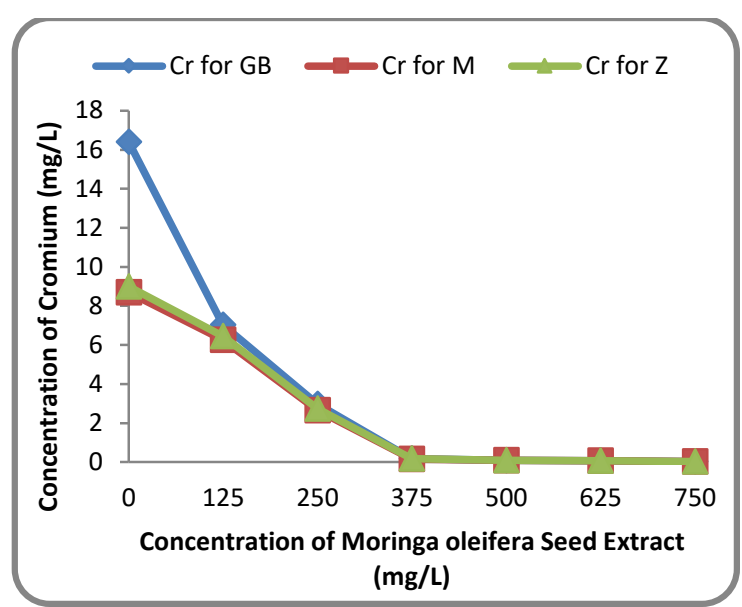

Figure 17: Chromium (Cr) Chart for $G_{B}$, Muhaza and Z-Tanneries Limited.

The concentration of copper in $\mathrm{G}_{\mathrm{B}}$, Muhaza and Z-tanneries were found to be $5.80 \mathrm{mg} / \mathrm{L}, 4.40 \mathrm{mg} / \mathrm{L}$ and $3.97 \mathrm{mg} / \mathrm{L}$ respectively which was significantly higher than the NESREA guidelines for tannery wastewater of $0.5 \mathrm{mg} / \mathrm{L}$. The concentration of copper was reduced from $5.80 \mathrm{mg} / \mathrm{L}$ $0.23 \mathrm{mg} / \mathrm{L}, 4.40 \mathrm{mg} / \mathrm{L}-0.18 \mathrm{mg} / \mathrm{L}$ and $3.97 \mathrm{mg} / \mathrm{L}-0.16 \mathrm{mg} / \mathrm{L}$ for the three tanneries at $500 \mathrm{mg} / \mathrm{L}$ of Moringa oleifera seed extract and this clearly shows an efficient removal of copper at $96.03 \%, 95.91 \%$ and $96.00 \%$ respectively. It was observed that Moringa oleifera consists of adsorption and neutralization of the colloidal positive charges that attract the negatively charged impurities and metals in water as shown in Figure 18.

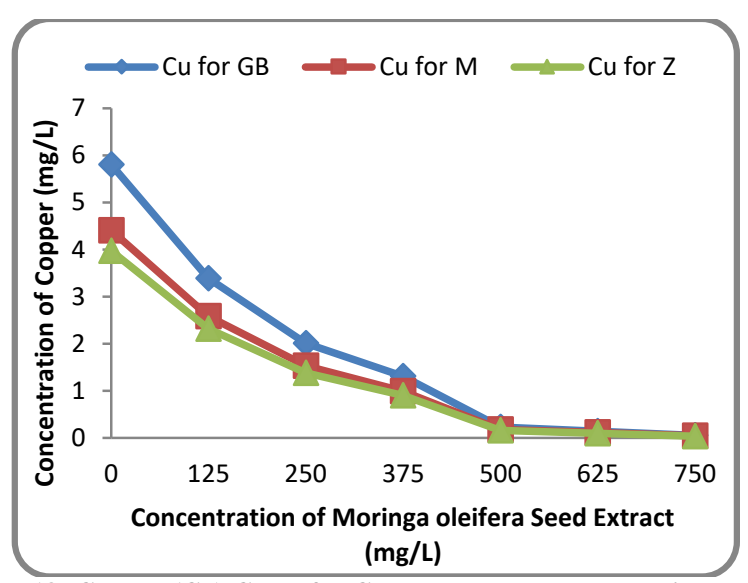

Figure 18: Copper (Cu) Chart for $G_{B}$, Muhaza and Z-Tanneries Limited.

The concentration of cobalt found in $\mathrm{G}_{\mathrm{B}}$ tannery, Muhaza tannery and Z-tannery was significantly higher than the NESREA guidelines for tannery wastewater of $0.5 \mathrm{mg} / \mathrm{L}$, with the $\mathrm{G}_{\mathrm{B}}$ tannery exhibiting a higher value of $1.80 \mathrm{mg} / \mathrm{L}$, Muhaza tannery exhibiting a value of $1.90 \mathrm{mg} / \mathrm{L}$ and Z-tannery was found to be $2.85 \mathrm{mg} / \mathrm{L}$ respectively. The concentration of cobalt reduced from $1.80 \mathrm{mg} / \mathrm{L}-0.08 \mathrm{mg} / \mathrm{L}, 1.90 \mathrm{mg} / \mathrm{L}-0.08$ $\mathrm{mg} / \mathrm{L}$ and $2.85 \mathrm{mg} / \mathrm{L}-0.13 \mathrm{mg} / \mathrm{L}$ at $375 \mathrm{mg} / \mathrm{L}$ of Moringa oleifera seed extract and this shows an efficient removal of cobalt at $95.56 \%, 95.79 \%$ and $95.55 \%$ respectively from tannery waste water. It was observed that Moringa oleifera consists of adsorption and neutralization of the colloidal positive charges that attract the negatively charged impurities and metals in water as shown in Figure 19.

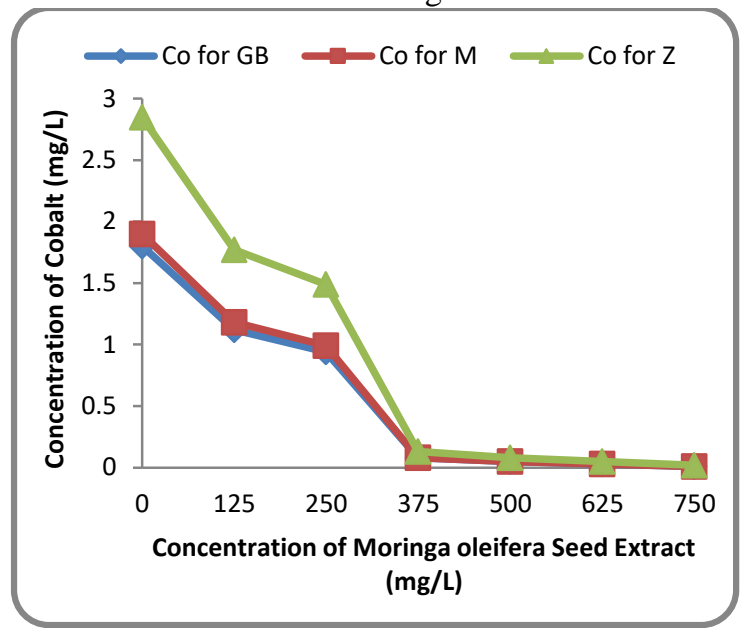

Figure 19: Cobalt (Co) Chart for $G_{B}$, Muhaza and Z-Tanneries Limited.

Although, the concentration of iron was not specified by NESREA agency for tannery wastewater but metal iron exhibiting a higher value of $1.4 \mathrm{mg} / \mathrm{L}$ in $\mathrm{G}_{\mathrm{B}}$ tannery, Muhaza tannery exhibiting a value of $1.10 \mathrm{mg} / \mathrm{L}$ and Z-tannery exhibiting $1.49 \mathrm{mg} / \mathrm{L}$ and at the end of the research the concentration of iron reduced from $1.40 \mathrm{mg} / \mathrm{L}-0.01 \mathrm{mg} / \mathrm{L}$, $1.10 \mathrm{mg} / \mathrm{L}-0.01 \mathrm{mg} / \mathrm{L}$ and $1.49 \mathrm{mg} / \mathrm{L}-0.01 \mathrm{mg} / \mathrm{L}$ at 500 $\mathrm{mg} / \mathrm{L}$ of Moringa oleifera seed extract and this shows an efficient removal of iron at $99.29 \%, 99.09 \%$ and $99.33 \%$ respectively from tannery waste water. It was observed that Moringa oleifera consists of adsorption and neutralization of the colloidal positive charges that attract the negatively charged impurities and metals in water as shown in Figure 20.

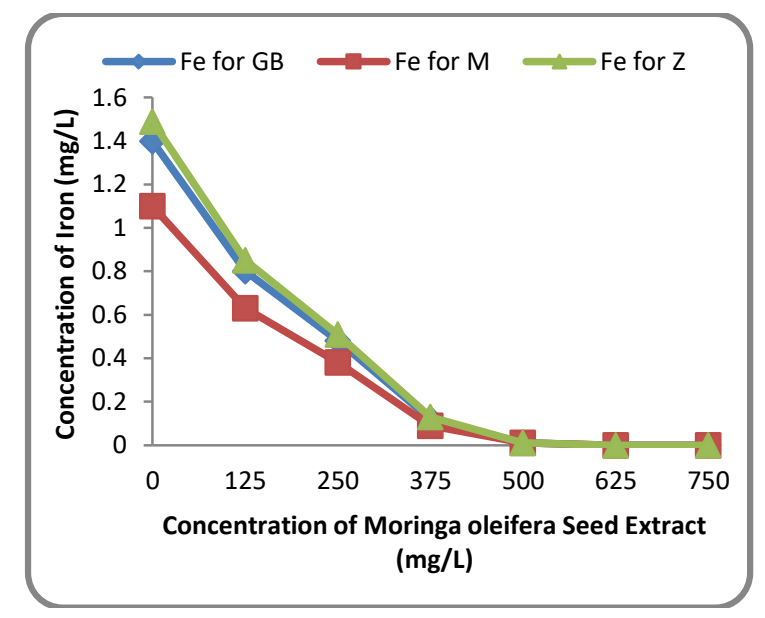

Figure 20: Iron (Fe) Chart for $G_{\mathrm{B}}$, Muhaza and Z-Tanneries Limited. 
The concentration of lead found in $\mathrm{G}_{\mathrm{B}}$ tannery, Muhaza tannery and Z-tannery was significantly higher than the NESREA guidelines for tannery wastewater of $0.1 \mathrm{mg} / \mathrm{L}$, with the $\mathrm{G}_{\mathrm{B}}$ tannery exhibiting a higher value of $1.90 \mathrm{mg} / \mathrm{L}$, Muhaza tannery exhibiting a value of $1.40 \mathrm{mg} / \mathrm{L}$ and Z-tannery was found to be $1.73 \mathrm{mg} / \mathrm{L}$ respectively. The concentration of lead reduced from $1.90 \mathrm{mg} / \mathrm{L}-0.06 \mathrm{mg} / \mathrm{L}, 1.40 \mathrm{mg} / \mathrm{L}-0.04 \mathrm{mg} / \mathrm{L}$ and $1.73 \mathrm{mg} / \mathrm{L}-0.06 \mathrm{mg} / \mathrm{L}$ at $500 \mathrm{mg} / \mathrm{L}$ of Moringa oleifera seed extract and this shows an efficient removal of lead at $96.84 \%, 97.14 \%$ and $96.53 \%$ respectively from tannery waste water. It was observed that Moringa oleifera consists of adsorption and neutralization of the colloidal positive charges that attract the negatively charged impurities and metals in water as shown in Figure 21.

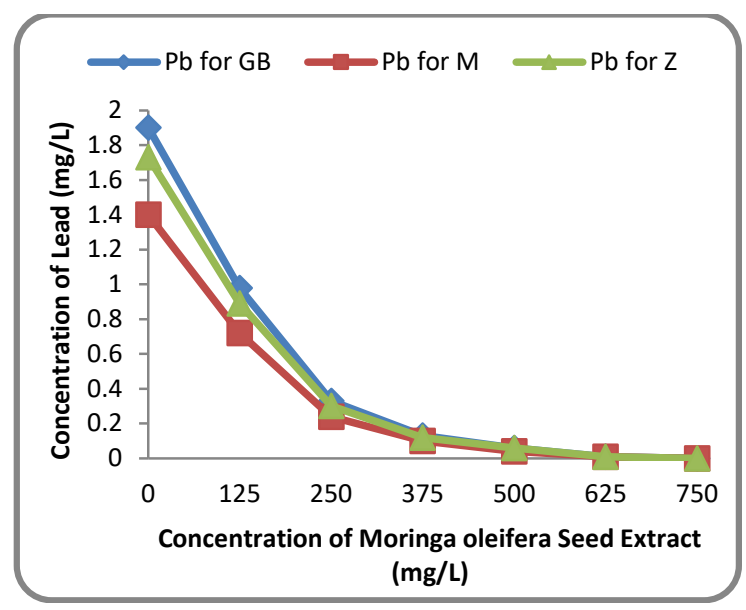

Figure 21: Lead (Pb) Chart for GB, Muhaza and Z-Tanneries Limited.

The concentration of manganese found in $G_{B}$ tannery, Muhaza tannery and Z-tannery was significantly higher than the NESREA guidelines for tannery wastewater of $1.0 \mathrm{mg} / \mathrm{L}$, with the $G_{B}$ tannery exhibiting a higher value of $2.70 \mathrm{mg} / \mathrm{L}$, Muhaza tannery exhibiting a value of $3.00 \mathrm{mg} / \mathrm{L}$ and Z-tannery was found to be $1.99 \mathrm{mg} / \mathrm{L}$ respectively. The concentration of manganese reduced from $2.70 \mathrm{mg} / \mathrm{L}-0.34 \mathrm{mg} / \mathrm{L}, 3.00 \mathrm{mg} / \mathrm{L}-$ $0.38 \mathrm{mg} / \mathrm{L}$ and $1.99 \mathrm{mg} / \mathrm{L}-0.25 \mathrm{mg} / \mathrm{L}$ at $375 \mathrm{mg} / \mathrm{L}$ of Moringa oleifera seed extract and this shows an efficient removal of cobalt at $87.41 \%, 87.33 \%$ and $87.44 \%$ respectively from tannery waste water. It was observed that Moringa oleifera consists of adsorption and neutralization of the colloidal positive charges that attract the negatively charged impurities and metals in water as shown in Figure 22.

The concentration of zinc found in $G_{B}$ tannery, Muhaza tannery and Z-tannery was significantly higher than the NESREA guidelines for tannery wastewater of $2.00 \mathrm{mg} / \mathrm{L}$, with the $\mathrm{G}_{\mathrm{B}}$ tannery exhibiting a higher value of $10.40 \mathrm{mg} / \mathrm{L}$, Muhaza tannery exhibiting a value of $11.20 \mathrm{mg} / \mathrm{L}$ and $\mathrm{Z}$ tannery was found to be $9.93 \mathrm{mg} / \mathrm{L}$ respectively. The

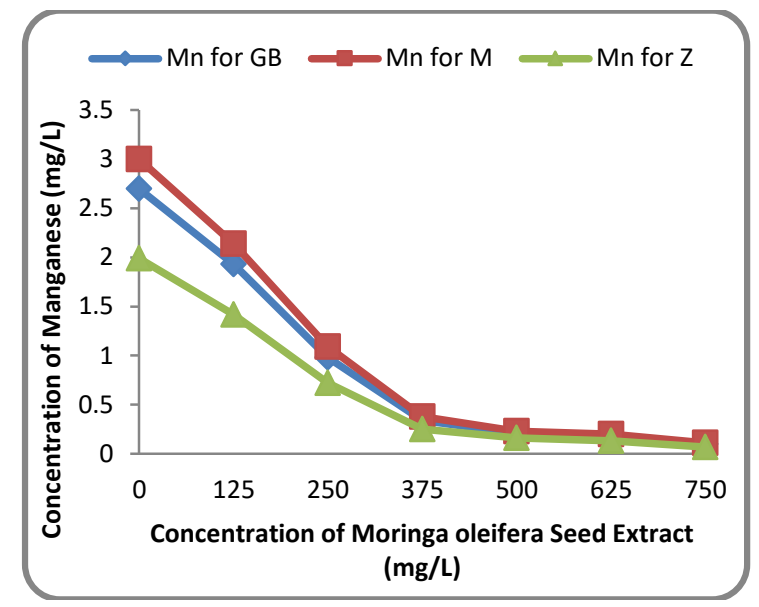

Figure 22: Manganese (Mn) Chart for $G_{B}$, Muhaza and Z-Tanneries Limited.

concentration of zinc reduced from $10.40 \mathrm{mg} / \mathrm{L}-0.90 \mathrm{mg} / \mathrm{l}$, $11.20 \mathrm{mg} / \mathrm{L}-0.97 \mathrm{mg} / \mathrm{L}$ and $9.93 \mathrm{mg} / \mathrm{L}-0.86 \mathrm{mg} / \mathrm{L}$ at 500 $\mathrm{mg} / \mathrm{L}$ of Moringa oleifera seed extract and this shows an efficient removal of zinc at $91.35 \%, 91.34 \%$ and $91.34 \%$ respectively from tannery waste water as shown in Figure 23.

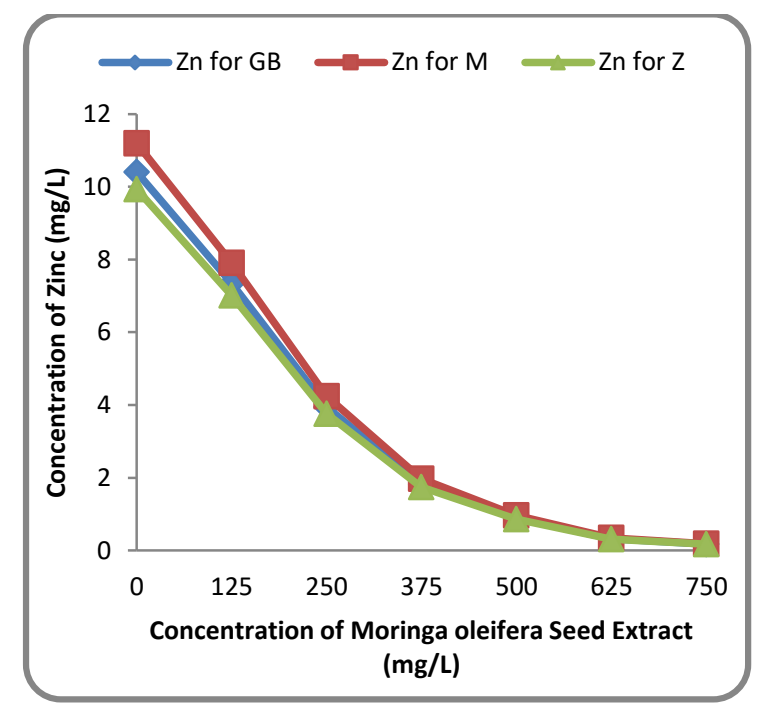

Figure 23: Zinc (Zn) Chart for $\mathbf{G}_{\mathrm{B}}$, Muhaza and Z-Tanneries Limited.

\section{CONCLUSION}

Based on the study test results, the following conclusions were drawn.

a) The study showed efficient removal of heavy metals from the three tannery wastewater using seed extract and gave the removal efficiency as follow; cadmium, chromium, and iron were reduced below the guidelines at the same removal efficiency of $99.29 \%$ while copper, cobalt, lead, manganese and zinc reduced at $96.03 \%, 95.56 \%, 96.84 \%$, $87.41 \%$ and $91.35 \%$ respectively. Therefore, it can be concluded that Moringa oleifera seed extract can 
effectively be used to remove heavy metals from tannery wastewater.

b) The optimum dosages of various Moringa oleifera seed extract were found to be $750 \mathrm{mg} / \mathrm{L}$ for cadmium, $625 \mathrm{mg} / \mathrm{L}$ for chromium, $500 \mathrm{mg} / \mathrm{L}$ for copper, iron, lead and zinc while $375 \mathrm{mg} / \mathrm{L}$ for manganese and cobalt for wastewater samples containing heavy metal concentrations in $G_{B}$ tannery, Muhaza tannery and Z-tannery industries. This study revealed a significant reduction of both physicochemical and heavy metal parameters of tannery wastewater when treated with the Moringa oleifera seed extract.

\section{REFERENCES}

Bai, R.S. and Abraham, T.E (2003). Low-cost supports used to immobilize fungi and reliable technique for removal hexavalent chromium in wastewater. Bioresource Technology, 87(17): 17-26

Bichi, M. H. (2013). A review of the Application of moringa oliefera seeds extract in water treatment, Civil and Environment Research Jornal, 3(8): 1-10.

Bichi, M. H.; J. C. Agunwamba; S. A. Muyibi and M. I. Abdulkarim. (2012a). Effect of Extraction Method on the Antimicrobial Activity of Moringa Oleifera Seeds Extract. Journal of American Science, 8(9): 450-458.

Bichi, M. H.; J. C. Agunwamba and S. A. Muyibi. (2012b). Optimization of Operating Conditions for the Application of Moringa Olifera (Zogale) Seeds Extract in Water Disinfection Using Response Surface Methodology. African Journal of Biotechnology, 11(92): 15875-15887.
Jahn, S. A. A. (1986). Proper use of African Natural coagulants for rural water supplies- Research in the Sudan and a guide to new projects; GTZ manual NO. 191.

Muyibi, S.A., and Evison, L.M. (1995a). Moringa Oleifera seeds for softening hard water. Water Research. 29(4): 1099-1105.

Muyibi, S. A. and Evison, L. M (1995b). Optimizing physical parameters affecting coagulation of turbidwater with Moringa Oliefera seed; Wat. Res., 29(12): PP 2689-2695

NESREA Guidelines. National Environmental Standards and Regulations Enforcement Agency.

Petroni S. L. G.; M. A. F. Pires and C. S. Munita. (2000). Adsorooo de zinco e codmio em colunas deturfa. Qusmica Nova, 23(4): 477-81.

Sani, M.A. (1990). The use of Zogale (Moringa Oliefera) for water treatment, B. Eng Final Year project; Bayero University, Kano, Nigeria.

Suarez, M.; M. Haenni.; S. Canarelli.; F. Fisch.; P. Chodanowski.; C. Servis.; O. Michielin.; R. Freitag.; P. Moreillon and N. Mermod. (2005). Structure-Function characterization and Optimization of a plant-Derived Antibacterial Peptide. Antimicrobial Agents and Chemotherapy: 49(9): 3847-3857.

Udosen, E.D. (2006). Determination of trace metals and fluxes in sediments along a segments of Qua Ibeo River in Southern Nigeria. Journal of Natural and Applied Sciences, 2(1): 82-90. 